\title{
Infection control of dental implant hand drivers using ethanol solution
}

\author{
Song-Yi Yu, Jin-Han Lee* \\ Department of Prosthodontics, College of Dentistry, Wonkwang University, Iksan, Republic of Korea
}

Purpose: The purpose of this study was to study the effects of the utilization of ethanol solution in infection control of dental implant hand drivers, a common practice in dental prosthodontic clinics. Materials and Methods: Infection control methods were divided into two groups. One swabbed with $83 \%$ ethanol gauze and the other immersed in $83 \%$ ethanol solution for $30,60,90$, $120,150,180$ and 300 second intervals after inoculation of the dental implant hand drivers with Staphylococcus aureus. After measuring the number of colony forming units and analyzing the optical density, the effects of infection control in the experimental group were compared with the positive control group without infection control after inoculation with bacteria and the negative control group without inoculation with bacteria after sterilization. Results: The number of colony forming units and optical density analysis showed a statistically significant difference compared to the positive control. On the other hand, there was no statistically significant difference between the negative control and the group immersed in the $83 \%$ ethanol solution for more than 150 seconds. Conclusion: It is recommended to use the ethanol solution as a pre-cleaning process before sterilization, since the intermediatelevel disinfection method using ethanol solution alone for the infection control of the dental implant hand driver cannot clinically secure the sterility. (J Dent Rehabil Appl Sci 2020;36(3):158-67)

Key words: infection control; dental implants; dental instruments; Staphylococcus aureus; ethanol; disinfection

\section{서론}

치과 의료진은 환자의 구강 조직과 직접 접촉하는 기 구들을 취급하기 때문에 환자의 타액과 혈액에 존재하는 다양한 감염원에 노출되어 있다. ${ }^{1}$ 그러므로 치과 의료진 이 감염성 질환에 걸릴 위험도는 타 직업군 보다 높다고 알려져 있다. ${ }^{2}$ 치과 진료실에서 전파될 수 있는 감염성 질 환은 단순한 감기에서부터, 폐렴, 결핵, 단순 포진, 간염 및 후천성 면역 결핍증까지 다양하다. ${ }^{3}$ 치과 진료의 특성 상 고속 핸드피스나 진동 스케일러를 사용하기 때문에 치료 과정에서 발생하는 에어로졸은 환자와 치과 의료진 간, 환자와 환자 간의 감염을 유발할 수 있다. 치과 보철 치료를 받는 다수의 환자들은 고령의 환자군으로 전염성

*Correspondence to: Jin-Han Lee

Professor, Department of Prosthodontics, College of Dentistry, Wonkwang University, 77 Doonsan-ro, Seo-gu, Daejeon, 35233, Republic of Korea Tel: +82-42-366-1150, Fax: +82-42-366-1115, E-mail: dentist@empas.com Received: May 21, 2020/Last Revision: June 29, 2020/Accepted: July 20, 2020
이 높은 질병에 취약할 뿐만 아니라 그러한 질병을 전염 시킬 수 있는 위험성이 높다고 알려져 있다. ${ }^{4}$ 따라서 치과 보철 진료 과정에서 교차 감염을 방지하기 위한 감염 관 리는 치과 의료진과 환자 모두에게 중요한 문제가 되었 다.

1970년대 이전의 감염 관리는 감염성 환자에만 집중하 여 시행되었다. 1980 년대에 이르러 Shaw 등 $^{5}$ 의 치과 의사 와 환자 간의 $\mathrm{B}$ 형 간염 바이러스의 전파에 대한 보고와, Robinson 등 ${ }^{6}$ 에 의한 치과 진료 과정에서 인간 면역 결 핍 바이러스의 전파에 대한 보고를 통하여 감염 관리의 대상이 치과 진료실에 내원하는 모든 환자로 확대되어야 함을 인식하게 되었다. 이후 환자와 치과 의료진, 치과 의 료진과 환자, 환자와 환자 간의 감염이 전파되는 것을 최 
소화하기 위해 치과 진료 환경에서의 감염 관리 가이드 라인이 제시되었고 2003년에 미국 질병 통제 및 예방 센 터에서는 모든 환자의 타액과 혈액을 잠재적인 감염원으 로 간주하고 감염 관리를 시행할 것을 권고하고 있다.

2017년 대한민국 질병 관리 본부에서 제시한 의료 기 관의 소독과 멸균에 대한 지침은 진료 과정 중에서의 모 든 조치를 감염 관리 프로토콜에 근거한 평가, 개인 보 호, 기구 세척 및 멸균, 소독, 치과 기공실 무균관리로 세 분화하여 시행하도록 하였다. ${ }^{8}$ 특히 치과 보철 진료와 관 련된 기구 세척 과정에 있어 멸균 전 침적, 사전 세척, 부 식 방지를 위한 건조 및 윤활, 포장, 높은 수준 소독 또는 멸균 등의 단계적 멸균법을 권장하고 있다. ${ }^{9}$

Brånemark에 의해 치과 임플란트가 도입된 후 많은 기 술적 발전으로 치과 임플란트를 이용한 치료는 결손 치 아의 수복에 필수적인 치료 방법이 되었다. ${ }^{10}$ 임플란트 수 술 과정에 사용하는 기구에 대한 감염 관리 방법은 확립 되어 각 제조사의 지시 사항에 명시되어 있다. ${ }^{11}$ 그러나 임플란트 보철을 위한 기구들의 감염 관리에 관한 제조 사의 지시 사항은 명확하게 제시되어 있지 않고, 이에 대 한 연구 또한 미흡한 실정이다. 이에 본 연구에서는 치과 보철 관련 기구 중 특히 치과 진료실에서의 사용 빈도가 높은 치과 임플란트 핸드 드라이버의 에탄올을 이용한 감염 관리 효과에 대하여 연구하고자 하였다.

\section{연구 재료 및 방법}

황색 포도상 구균(Staphylococcus aureus ATCC 33592, American Type Culture Collection, Manassas, USA)을 brain heart infusion (BHI) broth (Becton, Dickinson and Company, Franklin Lakes, USA) 액체 배지에 계대 배양하였다. 증식된 황색 포도상 구균(S. aureus)을 $50 \mathrm{ml}$ 튜브(Conical tube, SPL, Pocheon, Korea)에 넣고 $37^{\circ} \mathrm{C}$ 의 항온기에서 24 시간 동안 배양하여 세균 수가 $1 \times 10^{8}$ $\mathrm{CFU} / \mathrm{ml}$ 이 되게 하였다. 멸균된 상태의 동일한 치과 임 플란트 핸드 드라이버(1.2 mm Hex Long $28 \mathrm{~mm}$ Hand Driver, Osstem, Seoul, Korea) 40개 중에 세균의 접종을 시행하지 않는 음성 대조군을 제외한 36개를 각각 세균이 배양된 튜브에 넣고 5 분간 침적하여 접종을 시행하였다 (Table 1).

황색 포도상 구균이 접종된 치과 임플란트 핸드 드라 이버에 대한 감염관리 방법에 따라 (1) 에탄올 거즈로 닦 아낸(swab) 군과 (2) 에탄올 용액에 침적한 군으로 나
Table 1. Classification of experimental groups and control groups

\begin{tabular}{llrc}
\hline \multicolumn{1}{c}{ Group } & $\begin{array}{c}\text { Infection control } \\
\text { method }\end{array}$ & $\begin{array}{c}\text { Time } \\
\text { (second) }\end{array}$ & $\mathrm{N}$ \\
\hline Positive control & & & 4 \\
Experimental group & Swab & 30 & 4 \\
& Immersion & 30 & 4 \\
& Immersion & 60 & 4 \\
& Immersion & 90 & 4 \\
& Immersion & 120 & 4 \\
& Immersion & 150 & 4 \\
& Immersion & 180 & 4 \\
& Immersion & 300 & 4 \\
Negative control & & & 4 \\
\hline
\end{tabular}

누었다(Fig. 1). (1) 군은 황색 포도상 구균이 접종된 치 과 임플란트 핸드 드라이버를 멸균된 핀셋으로 꺼낸 뒤, $83 \%$ 에탄올(Antiseptic Ethanol, Firson, Cheonan, Korea)을 적신 $2 \times 2$ 거즈를 이용하여 30 초 동안 닦았 다. (2) 군은 세균이 접종된 치과 임플란트 핸드 드라이버 를 멸균된 핀셋으로 꺼낸 뒤, $83 \%$ 에탄올이 들어 있는 50 $\mathrm{ml}$ 튜브에 각각 30 초, 60 초, 90초, 120초, 150초, 180초, 300 초 동안 침적하였다. 이후 침적 시간이 다른 각각의 에탄올 튜브에서 치과 임플란트 핸드 드라이버를 꺼내 어 BHI broth 액체 배지가 들어있는 $15 \mathrm{ml}$ tube에 넣었 다. 치과 임플란트 핸드 드라이버가 들어있는 BHI broth 액체 배지 튜브를 vortex (Vortex Genie-2 Shaker, Scientific Industriea, New York, USA) 하여 치과 임플란트 핸드 드라이버 표면에 잔존한 균들을 분리하였다. $\mathrm{BHI}$ broth 액체 배지 튜브에서 멸균된 핀셋을 이용하여 치과 임플란트 핸드 드라이버를 제거하였다. 세균 접종 후 감 염 관리를 시행하지 않은 치과 임플란트 핸드 드라이버 를 양성 대조군으로 하고, 멸균 후 세균을 접종하지 않은 치과 임플란트 핸드 드라이버를 음성 대조군으로 하였다.

치과 임플란트 핸드 드라이버 표면에서 분리한 균 을 확인하기 위하여 육안으로 세균 집락 형성 단위 수 (colony forming unit) 세는 방법과 BHI broth 액체 배 지의 흡광도를 측정하는 방법을 사용하였다. 치과 임플 란트 핸드 드라이버를 제거한 BHI broth 배지의 용액을 마이크로피펫(Acura manual 825 manual micropipette, Socorex, Ecublens, Switzerland)을 이용하여 $100 \mu$ 를 pipetting 후 멸균된 $900 \mu \mathrm{l} \mathrm{BHI} \mathrm{broth} \mathrm{액체} \mathrm{배지가} \mathrm{들어}$ 


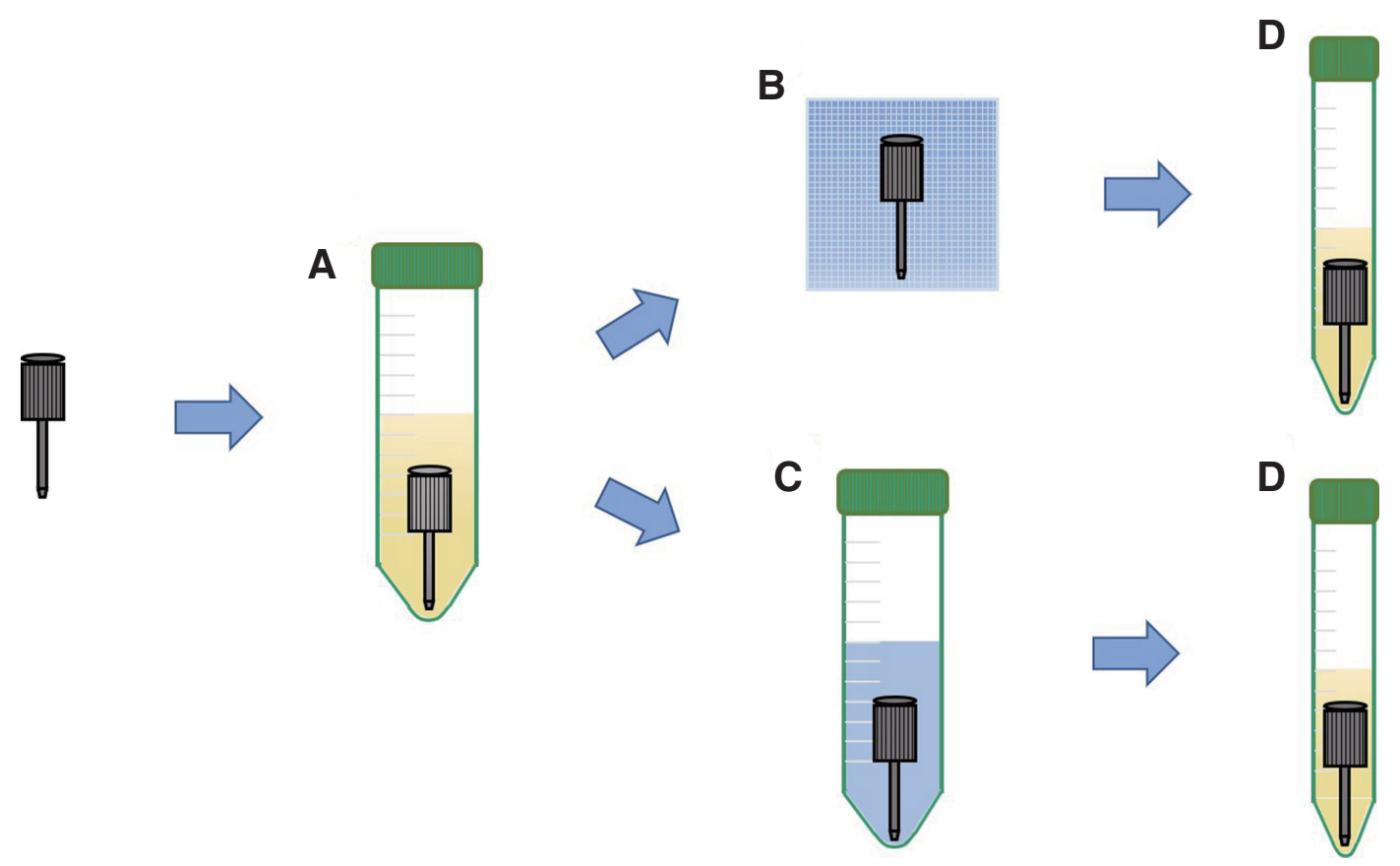

Fig. 1. Schematic drawing of the inoculation and the infection control methods. (A) Inoculation of the dental implant hand driver with S. aureus $1 \times 10^{8} \mathrm{CFU} / \mathrm{ml}$, (B) Swab with $2 \times 2$ gauze soaked with $83 \%$ ethanol solution, (C) Immersion in $83 \%$ ethanol solution, (D) Immersion in brain heart infusion broth after each infection control methods.

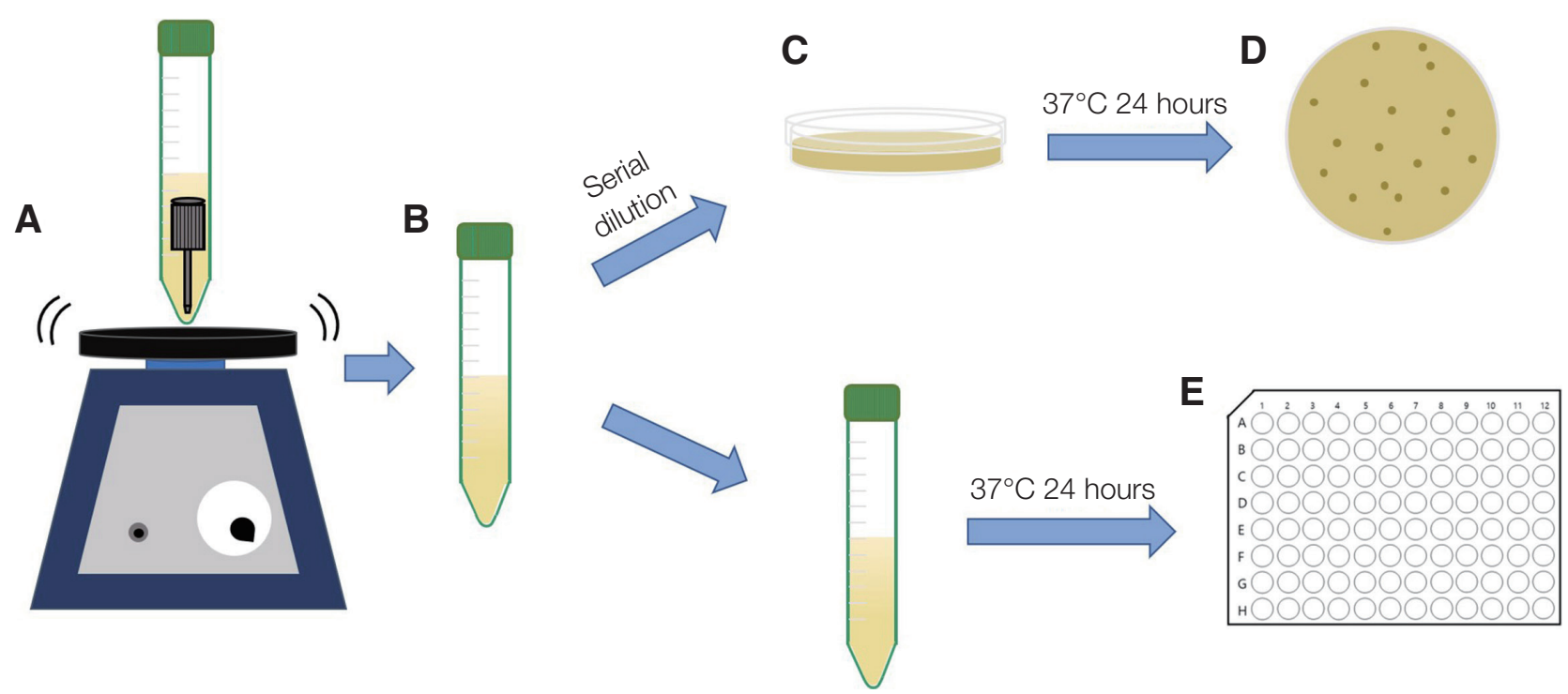

Fig. 2. Schematic drawing of the evaluation methods of the infection control methods. (A) Vortex a BHI broth tube with the dental implant hand driver after the infection control methods, (B) BHI broth with removal of the dental implant hand driver, (C) Spreading on the BHI agar plates with serial dilution method from $\times 10^{\circ}$ to $\times 10^{6}$, (D) Colony forming unit counting after incubation of the BHI agar plates, (E) OD610 nm measurement after incubation of the BHI broth . 
있는 $1 \mathrm{ml}$ test tube에 분주하여 10 배 희석하였다. 10 배씩 희석하는 과정을 6 번 반복하였다. 각 군당 희석하지 않은 BHI broth 액체 배지 용액(Fig. 2B)에서부터 $10^{6}$ 배까지 단계적으로 희석한 용액을 모두 $100 \mu \mathrm{l}$ 씩 분주하여 각 각 brain heart infusion agar plate (Glycerol, Biosesang, Seongnam, Korea)에 도말하였다. 도말이 완료된 BHI agar plate를 $37^{\circ} \mathrm{C}$ 항온기에서 24시간 동안 배양하였 다. 항온기에서 배양 후(Fig. 2D) 1 명의 숙련된 관찰자가 $\mathrm{BHI}$ agar plate 위의 $\mathrm{CFU}$ 를 세었다.

또한 BHI broth 액체 배지의 흡광도 측정을 위하여 에 탄올을 이용한 감염 관리 후 치과 임플란트 핸드 드라이 버를 제거한 $\mathrm{BHI}$ broth 액체 배지를 $37^{\circ} \mathrm{C}$ 항온기에서 24시간 동안 배양하였다. 배양 후 BHI broth 액체 배지 를 $100 \mu$ l씩 96 well plate에 분주 후 Microplate reader (Sunrise absorbance reader, Tecan, Männedorf, Switzerland)를 이용하여 $610 \mathrm{~nm}$ 에서 흡광도를 측정하였다(Fig. 2E).

각 실험군 당 4 개의 표본에 대하여 일련의 실험 과정을 시행하였다. 그리고 전체 실험 과정을 독립적으로 3 회 반 복하여 시행하였다. 각각의 변수에 대하여 Shapiro-Wilk test 로 정규성 검정을 시행하였으며, 대조군과의 차이를 검정하기 위해 독립표본 $\mathrm{T}$ 검정법을 채택하였다. 그 값 은 평균 \pm 표준 편차로 나타냈고, 신뢰 수준 $95 \%(P<$ $0.05)$ 에서 통계적 유의성을 검증하였다. 모든 통계분석은
SPSS 프로그램(SPSS 26.0, IBM, Armonk, USA)을 이용 하여 시행하였다.

\section{결과}

\section{양성 대조군과의 감염 관리 효과 비교}

$37^{\circ} \mathrm{C}$ 항온기에서 24 시간 동안 배양된 $\mathrm{BHI}$ agar plate 중 각 실험군의 희석하지 않은 $\left(\times 10^{\circ}\right.$ dilution $) \mathrm{BHI}$ broth 액체 배지 용액이 도말된 사진을 촬영하였다(Fig. 3). 치 과 임플란트 핸드 드라이버를 30 초 간 에탄올 거즈로 닦 아낸 실험군에서 분리한 액체 배지가 도말된 BHI agar plate의 CFU 수는 치과 임플란트 핸드 드라이버에 황색 포도상 구균을 접종한 후 감염 관리를 시행하지 않은 양 성 대조군에 비하여 통계적으로 유의하게 적은 $\mathrm{CFU}$ 수 를 나타냈고, 에탄올 용액에 침적을 시행한 실험군은 양 성 대조군에 비하여 에탄올에 30초 이상 침적한 모든 실 험군에서 통계적으로 유의한 차이를 나타냈다(Table 2).

$\mathrm{BHI}$ broth 액체 배지를 $37^{\circ} \mathrm{C}$ 항온기에서 24시간 배양 후 흡광도를 측정한 결과 30 초 간 에탄올 거즈로 닦아낸 실험군의 경우 양성 대조군에 비하여 통계적으로 유의한 차이가 없었다. 에탄올 용액에 침적을 시행한 실험군의 결과 양성 대조군에 비하여 30초 이상 침적한 모든 실험 군에서 통계적으로 유의한 차이를 나타냈다(Table 3).
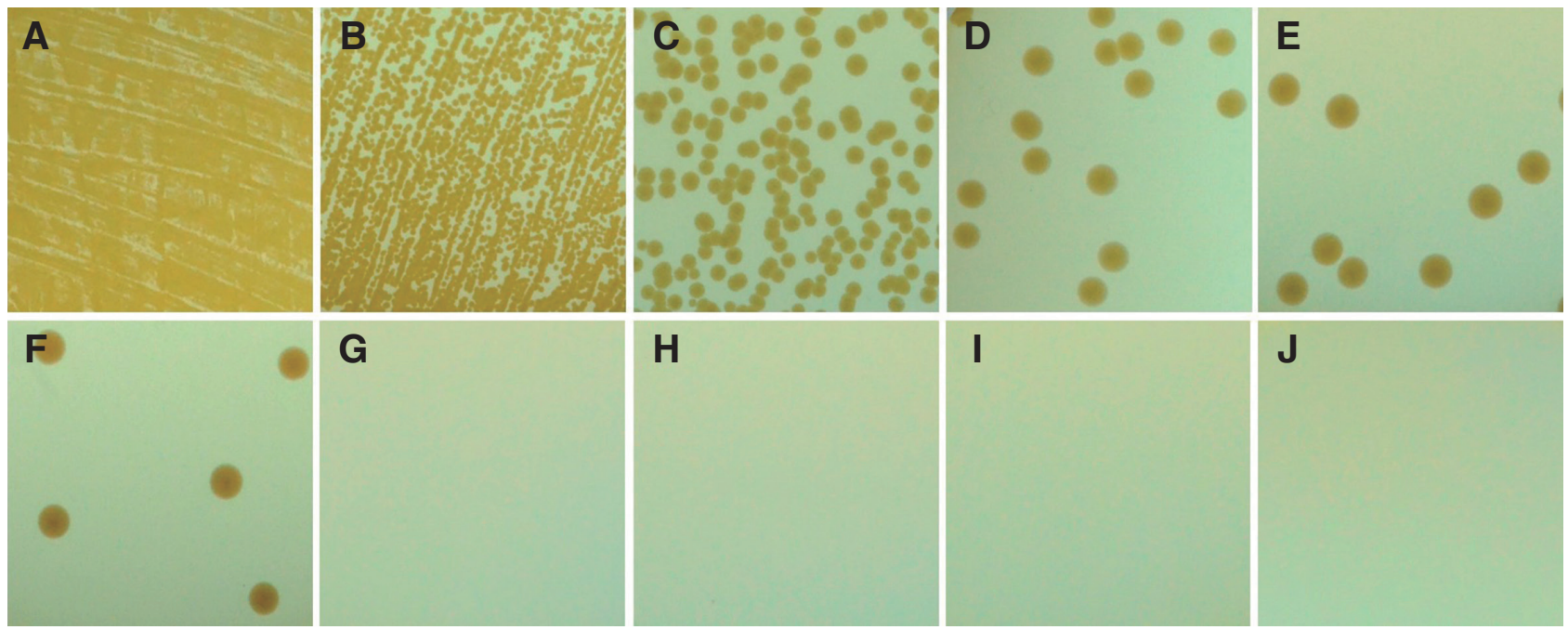

Fig. 3. Colony forming unit counting (1x). (A) Positive control, (B) 30 seconds Swab, (C) 30 seconds Immersion, (D) 60 seconds Immersion, (E) 90 seconds Immersion, (F) 120 seconds Immersion, (G) 150 seconds Immersion, (H) 180 seconds Immersion, (I) 300 seconds Immersion, (J) Negative control. Photographs of BHI agar plates with spreading the BHI broth with $\times 10^{\circ}$ dilution cropped by $35 \mathrm{~mm} \times 35 \mathrm{~mm}$. 
Table 2. $S$. aureus strains of implant hand drivers with infection controlled compared by positive control

\begin{tabular}{|c|c|c|c|}
\hline Group & Infection control method & $\mathrm{CFU} / \mathrm{ml}$ & $P$-value \\
\hline Positive control & & $1669167.00 \pm 221542.50$ & \\
\hline \multirow[t]{8}{*}{ Experimental group } & 30 seconds swab & $46916.67 \pm 11797.21$ & $<0.001 * * *$ \\
\hline & 30 seconds immersion & $544.17 \pm 120.79$ & $<0.001 * * *$ \\
\hline & 60 seconds immersion & $201.17 \pm 117.33$ & $<0.001 * * *$ \\
\hline & 90 seconds immersion & $113.33 \pm 93.14$ & $<0.001 * * *$ \\
\hline & 120 seconds immersion & $61.17 \pm 43.52$ & $<0.001 * * *$ \\
\hline & 150 seconds immersion & $0.00 \pm 0.00$ & $<0.001 * * *$ \\
\hline & 180 seconds immersion & $0.00 \pm 0.00$ & $<0.001 * * *$ \\
\hline & 300 seconds immersion & $0.00 \pm 0.00$ & $<0.001 * * *$ \\
\hline Negative control & & $0.00 \pm 0.00$ & $<0.001 * * *$ \\
\hline
\end{tabular}

Data were presented as mean \pm standard deviation.

Positive control: implant hand driver; not disinfected after inoculation.

Student's t-tests were performed due to the normality of the data compared by positive control.

$* P<0.05,{ }^{*} * P<0.01,{ }^{* * *} P<0.001$.

Table 3. Optical density of implant hand drivers with infection controlled compared by positive control

\begin{tabular}{|c|c|c|c|}
\hline Group & Infection control method & OD & $P$-value \\
\hline Positive control & & $0.47 \pm 0.04$ & \\
\hline \multirow[t]{8}{*}{ Experimental group } & 30 seconds swab & $0.43 \pm 0.04$ & 0.087 \\
\hline & 30 seconds immersion & $0.29 \pm 0.05$ & $<0.001 * * *$ \\
\hline & 60 seconds immersion & $0.25 \pm 0.06$ & $<0.001 * * *$ \\
\hline & 90 seconds immersion & $0.24 \pm 0.05$ & $<0.001^{* * *}$ \\
\hline & 120 seconds immersion & $0.23 \pm 0.02$ & $<0.001^{* * *}$ \\
\hline & 150 seconds immersion & $0.08 \pm 0.12$ & $<0.001^{* * *}$ \\
\hline & 180 seconds immersion & $0.00 \pm 0.00$ & $<0.001 * * *$ \\
\hline & 300 seconds immersion & $0.00 \pm 0.00$ & $<0.001 * * *$ \\
\hline Negative control & & $0.00 \pm 0.00$ & $<0.001 * * *$ \\
\hline
\end{tabular}

Data were presented as mean \pm standard deviation.

Positive control: implant hand driver; not disinfected after inoculation.

Student's t-tests were performed due to the normality of the data compared by positive control.

$* P<0.05, * * P<0.01, * * * P<0.001$.

\section{음성 대조군과의 감염 관리 효과 비교}

30 초 간 에탄올 거즈로 닦아낸 실험군과 에탄올 용액 에 침적을 시행한 실험군에서 분리한 $\mathrm{BHI}$ broth 액체 배 지가 도말된 BHI agar plate의 CFU 수는 치과 임플란트 핸드 드라이버를 멸균 후 황색 포도상 구균을 접종하지 않은 음성 대조군과 비교하였을 때 에탄올 용액에 침적 을 시행한 실험군 중, 에탄올 용액에 150 초 이상 침적한 실험군에서 통계적으로 유의한 차이가 없었다(Fig. 4). 흡 광도 측정 결과 에탄올 용액에 침적을 시행한 실험군 중
에서 에탄올 용액에 150 초 이상 침적한 실험군에서 음성 대조군과 통계적으로 유의한 차이가 없었다(Fig. 5).

\section{고찰}

전염성이 높은 병원균의 감염 확산을 방지하기 위해서 치과 진료용 기구나 기자재 등의 소독과 멸균 과정은 반 드시 필요하다. 치과 진료실 및 치과 기공실에서 효과적 인 감염 관리 방법을 통하여 치과 의사, 치과 위생사, 치 과 기공사 및 환자 모두에게 발생할 수 있는 교차 감염을 


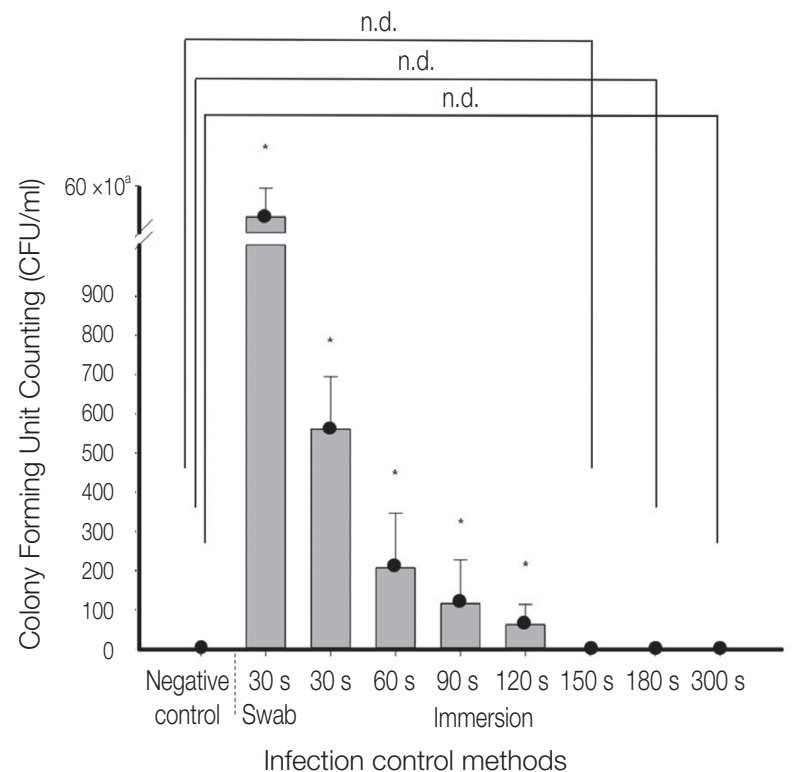

Fig. 4. S. aureus strains of the groups with infection control methods compared by negative control. Negative control: implant hand driver; not inoculated after autoclave method. Student's t-tests were performed due to the normality of the data compared by negative control. *Statistical significance $P<0.05$. n.d. (no difference).

방지하고, 감염 관리의 실패로 발생할 수 있는 사고를 미 연에 예방해야 한다. 치과 진료실에서 치과 진료용 기구 의 소독과 멸균을 시행하기 이전에 물과 기계적 마찰, 세 제를 이용하여 기구의 오염을 제거하는 기구 세척 과정 이 필요하다. 기구 세척 이후 소독 및 멸균 과정을 시행하 게 된다. ${ }^{12}$

치과 진료에 사용하는 기구는 잠재적 감염성 질환의 전파 위험도에 따라 고위험 기구, 준위험 기구, 비위험 기 구로 분류할 수 있다. 1996년 미국 치과 의사 협회에서 발표한 감염 관리 권장 사항에 의하면 치과 임플란트 수 술 기구는 환자의 점막을 관통하거나 혈관계 또는 무균 조직에 사용하는 고위험 기구이므로 멸균 과정이 필요하 다. 반면 치과 임플란트 보철 치료 과정에서 사용되는 치 과 임플란트 핸드 드라이버는 무균 조직이나 혈관계에 삽입되지는 않으나 점막이나 손상된 피부에 접촉하는 기 구로 준위험 기구이다. 준위험 기구에 속하는 의료 기구 들은 모든 미생물과 일부 세균의 아포를 사멸시키는 정 도의 중간 수준 이상의 소독을 시행해야 한다. ${ }^{13}$ 하지만 치과 임플란트 수술 기구에 비해서 치과 임플란트 보철

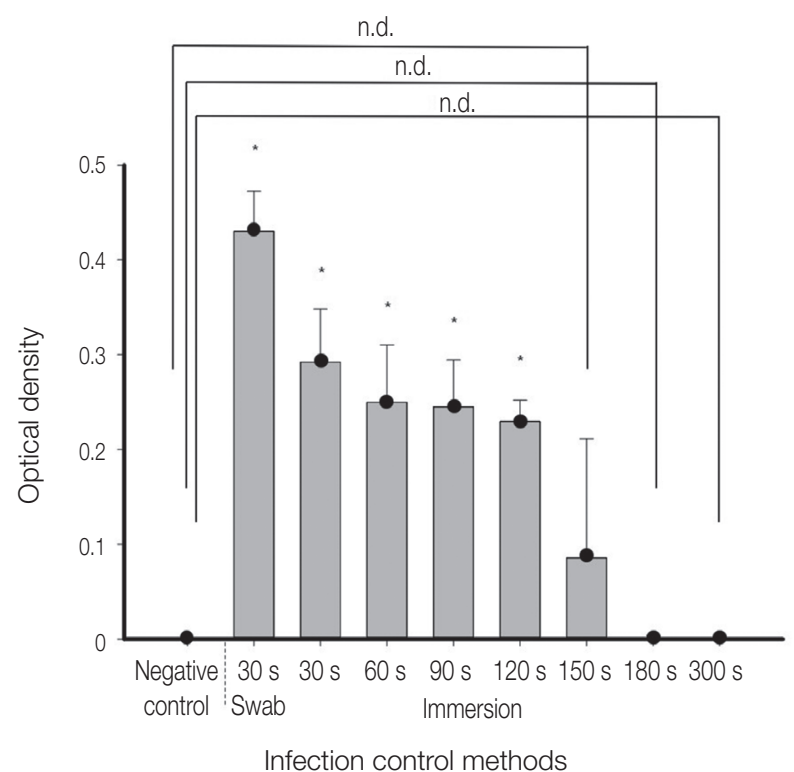

Fig. 5. Optical density results of the groups with infection control methods compared by negative control. Negative control: implant hand driver; not inoculated after autoclave method. Student's t-tests were performed due to the normality of the data compared by negative control. *Statistical significance $P<0.05$. n.d. (no difference)

기구로 인한 교차 감염의 위험성이 낮다는 인식으로 인 해 보철 진료용 기구들의 소독 및 멸균에 소홀해지기 쉽 다.

중간 수준 이상의 소독을 위한 소독액으로는 $7.5 \%$ 과 산화수소, 유효 염소량 $1000 \mathrm{ppm}$ 이상 차아염소산 나트 륨, $70-90 \%$ 농도의 알코올 제제 등을 이용한 방법이 있 다. ${ }^{14}$ 과산화수소는 하이드록실 프리라디칼을 생산하여 세포막의 지질, DNA, 기타 세포 필수 구성 요소 등을 파 괴한다. ${ }^{15}$ 염소 및 염소 화합물은 유리 염소가 미생물을 파괴하게 되는데 세포, 단백질 변성, 핵산의 불활성화 등 핵심적인 효소 반응의 저해와 관련된 것으로 알려져 있 다. ${ }^{16}$ 알코올은 $70-90 \%$ 농도에서 탈수로 인한 세균의 단백질 변성을 야기하여 살균 능력을 나타낸다. ${ }^{17}$ 하지만 높은 수준 소독을 위한 $7.5 \%$ 과산화수소 ${ }^{18}$ 와 유효 염소 농도가 $500 \mathrm{ppm}$ 이상인 염소 화합물 ${ }^{19}$ 은 금속의 부식을 야기할 수 있으므로 치과 임플란트 핸드 드라이버의 소 독 용액으로 부적합하다. 따라서 본 연구에서는 진료실 표면 소독 시 일반적으로 사용하는 $83 \%$ 에탄올을 사용 하여 치과 임플란트 핸드 드라이버의 감염 관리를 시행 
했을 경우의 감염 관리 효과를 알아보고자 하였다. 에탄 올 용액은 동일한 실험 조건을 위하여 매 실험마다 새로 운 용액을 사용하였다.

환자의 구강 내에는 상재균과 유해균이 존재한다. 황 색 포도상 구균은 건강한 사람의 비강 및 피부의 상재균 으로 존재하며 기회감염을 통해 국소 및 전신감염을 유 발하는 원내 감염의 원인균으로 화농성 감염의 $80 \%$ 이 상을 차지한다. ${ }^{20}$ 특히 치아 발치 및 관혈적 시술 이후의 세균 감염은 심장 판막의 염증을 유발할 수 있다. ${ }^{21}$ 또한 황색 포도상 구균은 일반적인 치주염과 달리 임플란트 주위 치주염에 이환된 환자의 치주 조직에서 특징적으로 나타나는 균주이다. ${ }^{22}$ 그러므로 본 연구에서는 원내 감염 을 유발할 수 있는 황색 포도상 구균을 감염원으로 간주 하고 치과 임플란트 핸드 드라이버 표면에 접종을 시행 하였다. 그리고 황색 포도상 구균의 사멸 정도를 평가하 기 위하여 BHI agar plate 위에 각각의 실험군에 해당하 는 액체 배지를 도말 후 $\mathrm{CFU}$ 수를 세는 방법과, 동시에 배양한 $\mathrm{BHI}$ broth 액체 배지 자체의 흡광도를 측정하는 방법을 사용하였다.

첫 번째 세균의 사멸 정도 평가 방법으로 세균의 $\mathrm{CFU}$ 수를 세는 방법에서, 세균의 농도가 높은 배양액을 $\mathrm{BHI}$ agar plate 위에 도말을 할 경우 육안으로 구별하기 어려 울 정도로 많은 $\mathrm{CFU}$ 수가 나타나게 된다. 그러므로 단 계적 희석 방법을 통하여 최적의 $\mathrm{CFU}$ 수가 되도록 희석 후 측정된 계수를 미지의 농도로 역추적하여 최종적으 로 $\mathrm{CFU}$ 수를 추정해야 한다. ${ }^{23} \mathrm{Wilson}{ }^{24}$ 에 의하면 최적의 $\mathrm{CFU}$ 수를 대략 100 - 400개 범위로 제시하였고, 본 연구 에서는 최적의 $\mathrm{CFU}$ 수가 되도록 배지를 최대 $10^{6}$ 배까지 순차적으로 희석하여 $\mathrm{CFU}$ 수를 세었다. 실험 과정에서 는 숙련된 실험자가 3 회 반복하여 무작위로 고체 배지의 $\mathrm{CFU}$ 수를 세었다.

두 번째 세균의 사멸 정도 평가 방법으로 액체 배지의 흡광도를 측정하였다. Beer's Law에 따르면 흡광도는 용 액의 농도에 비례하며 묽은 부유물에서 대부분의 세균의 세포 크기와는 무관하게 건조 중량의 농도 단위당 흡광 도가 거의 동일하다고 밝혀져 있다. ${ }^{25}$ 이런 이유로 미생물 의 성장을 신속하고 높은 정확도로 추정할 수 있는 방법 으로 흡광도 분석법이 많이 사용되고 있다. 본 연구에서 $1 \times 10^{8} \mathrm{CFU} / \mathrm{ml}$ 농도의 황색 포도상 구균의 경우 흡광 도 수치가 1.00 에 근접한 수치를 나타냈고, 세균을 접종 시키지 않은 멸균 상태의 음성 대조군에서는 흡광도 수 치가 0.00 에 근접한 수치를 나타냈다.
본 연구에서는 치과 임플란트 핸드 드라이버를 세균에 접종 후 에탄올 거즈를 이용하여 닦거나, 에탄올 용액에 침적을 시행하였을 때 감염 관리를 시행하지 않은 양성 대조군에 비하여 통계적으로 유의한 차이를 나타냈다. 그러나 세균의 사멸 정도를 구분하는 것보다 세균이 모 두 사멸되어 멸균 후 세균 접종을 시행하지 않은 음성 대 조군과 통계적으로 유의한 차이가 없는 지점을 파악하는 것이 임상적인 감염 관리의 측면에서 더 중요하다. $\mathrm{CFU}$ 수의 측정 결과와 흡광도 분석 결과에서 모두 $83 \%$ 에탄 올 용액에 150 초 이상 침적을 시행하였을 경우 멸균된 상 태의 음성 대조군과 통계적으로 유의한 차이를 나타내지 않았다.

본 연구의 제한점은 치과 임플란트 핸드 드라이버에 유기물 및 혈액이 묻지 않아 임상 조건과는 상이한 환경 이었다는 것이다. 연구 결과 수치상으로는 $83 \%$ 의 에탄 올 용액에 150 초 이상 침적하는 방법에서 멸균된 상태와 가까운 결과를 보였다. 하지만 실제 임상 환경에서는 세 균이 치과 임플란트 핸드 드라이버에 표면에 직접 부착 하는 것뿐만 아니라 치태 등의 유기물 또는 혈액과 같은 단백질에 부착할 수도 있으므로 신뢰할 만한 소독이 이 루어지지 않을 가능성이 있다. 따라서 금속의 치과 기구 의 감염 관리는 사전 세척 시행 후 고압 증기 멸균을 시 행해야 한다. 또한 치과 의료 기구의 감염 관리 방법을 명 확히 인지하고 있음에도 불구하고 이를 실제로 시행하는 실천도는 낮게 보고되고 있으므로 ${ }^{26}$ 치과에서 감염 관리 의 필요성을 인지하고 교육하는 것뿐만 아니라 동기부여 를 통한 실천 ${ }^{27}$ 을 할 수 있도록 노력해야 하겠다.

\section{결론}

본 연구에서는 치과 보철 관련 기구 중 사용 빈도가 높 은 치과 임플란트 핸드 드라이버의 에탄올 용액을 이용 한 감염 관리 방법의 유효성에 대해 연구하였다. 치과 임 플란트 핸드 드라이버를 $83 \%$ 에탄올 거즈로 30 초 동안 닦아낸 방법은 세균 수를 유의하게 감소시켰으나 24시 간 배양 후 세균이 배양되었다. $83 \%$ 에탄올 용액에 침적 하는 방법도 세균의 수는 유의하게 감소시켰으나 120 초 이하로 침적한 실험군에서는 24 시간 배양 후 세균이 배 양되었고, 150 초 이상 침적 시에는 세균이 배양되지 않았 다. 임상적으로 치과 기구의 멸균 과정의 목적은 세균 수 의 감소가 아닌 아포를 포함한 모든 미생물이 존재하지 않는 상태에 도달하는 것이다. 따라서 치과 임플란트 핸 
드 드라이버의 감염 관리를 위해 에탄올 용액을 단독으 로 사용한 중등도 소독 방법은 임상적으로 멸균 상태에 대한 확신을 보장할 수 없으므로 멸균 전 사전 세척 과정 으로서 에탄올 용액을 사용하는 것이 추천된다.

\section{Acknowledgements}

이 논문은 2019년 원광대학교 교내 지원에 의해 수행 되었음.

\section{ORCID}

Song-Yi Yu https://orcid.org/0000-0003-0002-5737

Jin-Han Lee https://orcid.org/0000-0001-9360-0635

\section{References}

1. Verran J, Kossar S, McCord JF. Microbiological study of selected risk areas in dental technology laboratories. J Dent 1996;24:77-80.

2. Younai FS. Health care-associated transmission of hepatitis B \& C viruses in dental care (dentistry). Clin Liver Dis 2010;14:93-104.

3. American Dental Association Council (ADA). Infection control recommendations for the dental office and the dental laboratory. Council on Dental Materials, Instruments, and Equipment. Council on Dental Practice. Council on Dental Therapeutics. J Am Dent Assoc 1988;116:241-8.

4. Connor C. Cross-contamination control in prosthodontic practice. Int J Prosthodont 1991;4:337-44

5. Shaw FE Jr, Barrett CL, Hamm R, Peare RB, Coleman PJ, Hadler SC, Fields HA, Maynard JE. Lethal outbreak of hepatits $\mathrm{B}$ in dental practice. JAMA 1986;255:3260-4.

6. Robinson P, Challacombe S. Transmission of HIV in a dental practice - the facts. Br Dent J 1993;175: 383-4.

7. Kohn WG, Collins AS, Cleveland JL, Harte JA, Eklund KJ, Malvitz DM. Centers for Disease Control and Prevention (CDC). Guidelines for infection control in dental health care settings. MMWR Recomm Rep 2003;52:1-61.

8. Korea Center for Disease Control \& Prevention
(KCDC). Guideline for prevention and control of Healthcare associated infections. Available from: http://is.cdc.go.kr/upload_comm/refile. do? $\mathrm{cmd}=$ fileDownloadC\&comfile_se $=$ tr7LGqXm $\mathrm{G}||^{\wedge}|| \mathrm{H}||^{\wedge}||$ 4gNkq9Xs1FbTVBXw3qniQFmL DPUCWeg=\&comfile_fs $=201907161556527315197$ $27 \&$ comfile_fn $=\% \mathrm{EC} \% 9 \mathrm{D} \% 98 \% \mathrm{~EB} \% \mathrm{~A} 3 \% 8 \mathrm{C} \% \mathrm{E}-$ A $\%$ B 4\%80\%EB $\%$ A0\%A $\%$ EA $\%$ B $\% \% 90 \%$ EC $\%$ $97 \% \mathrm{BC}+\% \mathrm{ED} \% 91 \% 9 \mathrm{C} \% \mathrm{EC} \% \mathrm{~A} 4 \% 80 \% \mathrm{EC} \% 98$ $\% 88 \%$ EB $\%$ B0\%A9\% EC $\%$ A $7 \% 80 \%$ EC $\%$ B $\%$ A $8 \% \mathrm{EC} \% 84 \% 9 \mathrm{C} \% 28 \% \mathrm{EC} \% 9 \mathrm{~B} \% \mathrm{~B} 9 \% \mathrm{EC} \% 9 \mathrm{~A} \%$ A9-\%EC\%88\%98\%EC\%A0\%95-20190712\%29. pdf\&comfile_c $=$ www1\&comfile_fd=1599701 414928 (updated 2020 Sep 17).

9. Alapatt JG, Varghese NM, Joy PT, Saheer MK, Correya BA. Infection Control in Dental Office: A Review. IOSR-JDMS 2016;15:10-5.

10. Abraham CM. A brief historical perspective on dental implants, their surface coatings and treatments. Open Dent J 2014;16:50-5.

11. Straumann ${ }^{\circledR}$ Dental Implant System. Guideline for cleaning, disinfection and sterilization. Available from: https://www.straumann.com/content/dam/ media-center/straumann/en/documents/brochure/technical-information/152.802-en_low.pdf (updated 2020 Sep 17).

12. Rutala WA, Weber DJ. Disinfection and sterilization in health care facilities: what clinicians need to know. Clin Infect Dis 2004;39:702-9.

13. American Dental Association Council (ADA). Infection control recommendations for the dental office and the dental laboratory. ADA Council on Scientific Affairs and ADA Council on Dental Practice. J Am Dent Assoc 1996;127:672-80.

14. Rutala WA, Weber DJ. Healthcare Infection Control Practices Advisory Committee. Guideline for Disinfection and Sterilization in Healthcare Facilities, 2008. Available from: https://www.cdc.gov/ infectioncontrol/pdf/guidelines/disinfectionguidelines-H.pdf (updated 2020 Sep 4).

15. Linley E, Denyer SP, McDonnell G, Simons C, Maillard JY. Use of hydrogen peroxide as a biocide: new consideration of its mechanisms of biocidal action. J Antimicrob Chemother 2012;67:1589-96.

16. Gottardi W, Debabov D, Nagl M. N-chloramines, a 
promising class of well-tolerated topical anti-infectives. Antimicrob Agents Chemother 2013;57:110714.

17. Morton HE. The relationship of concentration and germicidal efficiency of ethyl alcohol. Ann N Y Acad Sci 1950;53:191-6.

18. Sugama J, Uchida S, Yamashiro N, Morishima Y, Hirose T, Miyazawa T, Satoh T, Satoh Y, Iinuma K, Wada Y, Tachibana M. Effects of Hydrogen Peroxide on Corrosion of Stainless Steel, (II). J Nucl Sci Technol 2004;41:880-9.

19. Oliet S, Sorin SM. Inhibition of the corrosive effect of sodium hypochlorite on carbon steel endodontic instruments. J Endod 1978;4:12-6.

20. You YO, Kim KJ, Min BM, Chung CP. Staphylococcus lugdunensis - a potential pathogen in oral infection. Oral Surg Oral Med Oral Pathol Oral Radiol Endod 1999;88:297-302.

21. Etiene J, Fleurette J, Ninet JF, Farvet P, Gauer LD. Staphylococcal endocarditis after dental extraction. Lancet 1986;2:511-2.

22. Belibasakis GN, Charalampakis G, Bostanci N, Stadlinger B. Peri-implant infections of oral biofilm etiology. Adv Exp Med Biol 2015;830:69-84.

23. Ben-David A, Davidson CE. Estimation method for serial dilution experiments. J Microbiol Methods 2014;107:214-21.

24. Wilson GS. The proportion of viable bacteria in young cultures with special reference to the technique employed in counting. J Bacteriol 1922;7:40546.

25. Daalgard P, Ross T, Kamperman L, Neumeyer K, McMeekin TA. Estimation of bacterial growth rates from turbidimetric and viable count data. Int J Food Microbiol 1994;23:391-404.

26. Kim JH, Lee JH. The survey on the infection control of noncritical instruments used in dental treatment. J Dent Rehabil Appl Sci 2019;35:27-36.

27. Lee JH. The infection control of dental impressions. J Dent Rehabil Appl Sci 2013;29:183-93. 


\section{에탄올을 이용한 치과 임플란트 핸드 드라이버의 감염 관리에 대한 연구}

류송이 대학원생, 이진한* 교수

원광대학교 치과대학 치과보철학교실

목적: 치과 보철 진료 과정에서 사용 빈도가 높은 치과 임플란트 핸드 드라이버의 에탄올 용액을 이용한 감염 관리 효과 에 대하여 연구하고자 하였다.

연구 재료 및 방법: 36 개의 치과 임플란트 핸드 드라이버의 표면에 황색 포도상 구균을 접종 후 $83 \%$ 에탄올 거즈로 30 초 동안 닦아낸 군과 $83 \%$ 에탄올 용액에 30 초, 60 초, 90 초, 120 초, 150 초, 180 초, 300 초 동안 침적한 군으로 나누었다. 세균 집락 형성 단위 수의 측정 방법과 흡광도 분석 방법을 이용하여 실험군과 세균 접종 후 감염 관리를 시행하지 않은 양성 대조군 및 멸균 후 세균을 접종하지 않은 음성 대조군과의 비교를 통해 감염 관리 효과를 평가하였다.

결과: 세균 집락 형성 단위 수의 측정 결과와 흡광도 분석 결과에서 두 군 모두 양성 대조군에 비하여 통계적으로 유의한 차이를 나타냈다. 그리고 $83 \%$ 에탄올 용액에 침적한 군에서 150 초 이상의 침적을 시행하였을 경우 음성 대조군과 통계 적으로 유의한 차이를 나타내지 않았다.

결론: 치과 임플란트 핸드 드라이버의 감염 관리를 위해 에탄올 용액을 단독으로 사용한 중등도 소독 방법은 임상적으 로 멸균 상태에 대한 확신을 보장할 수 없으므로 멸균 전 사전 세척 과정으로서 에탄올 용액을 사용하는 것이 추천된다.

(구강회복응용과학지 2020;36(3):158-67)

주요어: 감염 관리; 치과 임플란트; 치과 기구; 황색 포도상 구균; 에탄올; 소독

*교신저자: 이진한

(35233) 대전광역시 서구 둔산로 77 원광대학교 대전치과병원 치과보철과

Tel: 042-366-1150 | Fax: 042-366-1115 | E-mail: dentist@empas.com

접수일: 2020년 5월 21일 | 수정일: 2020년 6월 29일 | 채택일: 2020년 7월 20일 